\title{
LOWER SERUM BCL-2 PROTEIN LEVELS IN SCHIZOPHRENIA PATIENTS TREATED WITH THE SECOND THAN THE FIRST GENERATION ANTIPSYCHOTICS
}

\author{
Vladimir V. Đorđević1,2
}

\begin{abstract}
Schizophrenia is one of the most severe psychiatric diseases the etiology of which remains unknown. Among the many factors involved in the pathophysiology of schizophrenia, a role of apoptosis has also been hypothesized. Bcl-2 protein is a potent inhibitor of apoptosis, showing in addition neurotrophic activity in the central nervous system. Since the expression of $\mathrm{Bcl}-2$ protein is increased in several neurodegenerative diseases and schizophrenia shows some of the features of a limited neurodegenerative disorder, it has been hypothesized that $\mathrm{Bcl}-2$ protein expression is altered in schizophrenia. In order to test this hypothesis, $\mathrm{Bcl}-2$ protein was determined in the sera from 30 patients with schizophrenia and from 30 age- and gender-matched healthy subjects using the ELISA method. Although the mean serum $\mathrm{Bcl}-2$ protein concentration was lower in patients with schizophrenia than in healthy volunteers, there was not any significant difference between the patient $(0.276 \pm 0.07 \mathrm{ng} / \mathrm{mL})$ and control $(0.332 \pm 0.22 \mathrm{ng} / \mathrm{mL})$ values. No significant difference was found between males and females either. Similar Bcl-2 concentrations were obtained in the group showing almost equally positive and negative symptoms $(0.275 \pm 0.068 \mathrm{ng} / \mathrm{mL})$, in the group with a relative predominance of positive symptoms $(0.283 \pm 0.082 \mathrm{ng} / \mathrm{mL})$ and in the group with a relative predominance of negative symptoms $(0.275 \pm 0.074 \mathrm{ng} / \mathrm{mL})$. Serum Bcl-2 protein concentration in patients treated with first generation antipsychotics was $0.301 \pm 0.075 \mathrm{ng} / \mathrm{mL}$, and it was significantly higher compared to the values in patients receiving second generation antipsychotics $(0.233 \pm 0.052 \mathrm{ng} / \mathrm{mL}, \mathrm{p}<0.05)$. There was not any significant correlation between serum Bcl-2 concentration and heredity, onset of the disease, number of psychotic episodes and duration of psychosis. To date and to the best of our knowledge, this has been the first demonstration of $\mathrm{Bcl}-2$ concentration in the sera of patients with schizophrenia, showing significantly different values between the patients treated with typical and those treated with atypical antipsychotics.
\end{abstract}

Acta Medica Medianae 2017;56(4):126-131.

Key words: schizophrenia, serum, Bcl-2 protein, antipsychotics

${ }^{1}$ University of Niš, Faculty of Medicine, Niš, Serbia

${ }^{2}$ Clinic for Mental Health Protection, Clinical Centre Niš, Niš, Serbia

Contact: Vladimir V. Đorđević

Bul. dr Zorana Đinđića 81,18000, Nišs, Serbia

E-mail: vladimir_dj@open.telekom.rs

\section{Introduction}

Schizophrenia is a complex and one of the most severe neuropsychiatric disorders, affecting up to $1 \%$ of the world population. It is characterized by cognitive impairments linked to behavioral changes $(1,2)$. It is considered a multifactorial disease caused by a combination of genetic and environmental factors (3). Among the many factors responsible for the development of schizo- phrenia, both pre- and postnatal, as well as those genetically determined, abnormalities of the apoptotic process should be considered as well (4). Apoptosis is a mechanism of cell death that operates in normal neurodevelopment. However, it occurs as a pathological feature in various neurological and psychiatric disorders (5). The activation of apoptosis can lead to the elimination of neurons and glia in the central nervous system (6). Evidence of subtle neurostructural changes following the onset of psychosis, shorter dendrites, reduced neutrophil count, reduction in neuronal and glial cell number as well as synaptic elements (4), indicates that apoptosis may significantly contribute to the pathophysiology of schizophrenia. Furthermore, dysregulation of apoptotic process in schizophrenia is documented in the brain (7) and peripheral blood (8). On the basis of known evidence, it is suggested that schizophrenia is associated with non-lethal apoptosis that leads to the defects of synaptic plasticity (9), neurodegenerative altera- 
tions (10) and immune system dysfunction (11), and all these disturbances may have a significant impact on cognitive impairments in schizophrenia.

$\mathrm{Bcl}-2$ protein is a member of the $\mathrm{Bcl}-2$ ( $\mathrm{B}$ cell lymphoma 2) family of proteins that regulate apoptotic cell death. To date, a total of 25 proteins have been identified in this family which have either pro- or anti-apoptotic activities. At least 15 $\mathrm{Bcl}-2$ family members have been identified in mammalian cells (12). Each family member contains one to four conserved regions which are named as $\mathrm{Bcl}-2$ homology domains (BH1-BH4) and which control the capability of these proteins to dimerize and regulate apoptotic cell death (13). Proteins which contain all four domains exert antiapoptotic activity, while the others exert pro-apoptotic effects. The ultimate vulnerability of cells to diverse apoptotic stimuli is determined by the relative ratio of various pro-apoptotic and antiapoptotic members of the $\mathrm{Bcl}-2$ family $(14,15)$. They control and regulate the intrinsic, mitochondrial apoptotic pathway by exercising control over mitochondrial membrane permeability. The main mechanism of action of the $\mathrm{Bcl}-2$ family of proteins is the regulation of cytochrome $\mathrm{c}$ release from the mitochondria. $\mathrm{Bcl}-2$ is an integral, membrane- associated protein, and a major anti-apoptotic protein that inhibits apoptotic and necrotic cell death induced by a diverse set of adverse conditions $(16,17)$. It controls the activation of caspase proteases and inhibits cytochrome $c$ release. $\mathrm{BCl}-2$ also plays critical roles in neuronal morphogenesis and synaptic plasticity $(18,19)$. In addition, it exerts antioxidant potentials, prevents the production of reactive oxygen species and controls calcium concentration in the cell.

The objective of this study was to evaluate serum $\mathrm{BCl}-2$ protein levels in patients with schizophrenia.

\section{Material and methods}

This study included 30 schizophrenic patients of either sex (19 males, 11 females; mean age, $31.1 \pm 8.1$ ) and 30 healthy individuals (19 males, 11 females; mean age $29.1 \pm 6.9$ ). All the patients were thoroughly screened and diagnosed for schizophrenia at the Clinic of Psychiatry and Clinic for Mental Health Protection of the Clinical Centre Niš, taking into account the presence of relevant symptoms and results of the Structured Clinical Interview for DSM-IV-TR. The patients were treated with first generation antipsychotics or second generation antipsychotics. Healthy control subjects were recruited from among the clinical staff. A complete clinical and personal history of schizophrenics was recorded. Psychopathological evaluation and clinical management of patients was done using the Positive and Negative Syndrome Scale (PANSS). The exclusion criteria for all study subjects included any serious neurological, endocrine, oncological, inflammatory, autoimmune, cerebrovascular, cardiac or metabolic disorder, as well as the history of receiving ECT in the last month or any substance abuse. The patients and controls were matched according to their age, sex, education, marital status, living conditions, living settings and habits. All subjects gave their informed consents to participate in the study, and the study was approved by the Clinical Centre Niš Ethics Committee.

Venous blood samples were collected in vacutainer tubes (Venosafe, Terumo Europe N.V., Leuven, Belgium) without any anticoagulant, the sera were separated as soon as possible after clotting by centrifugation at $3000 \mathrm{rpm}$ for $10 \mathrm{~min}$, and stored at $-20^{\circ} \mathrm{C}$ until $\mathrm{Bcl}-2$ protein determination. The concentrations of $\mathrm{Bcl}-2$ protein were determined using the ELISA method and available ELISA kits (solid phase sandwich ELISA assays) (Bender Med System, Vienna, Austria). The kit for Bcl-2 protein contained an antibody specific for human $\mathrm{BCl}-2$ protein. A coloured product was formed in proportion to the amount of $\mathrm{BCl}-2$ protein present in the sample. Absorbance was measured at 450 $\mathrm{nm}$, and $\mathrm{BCl}-2$ protein concentration determined according to a standard curve prepared from seven $\mathrm{Bcl}-2$ standard dilutions.

\section{Statistical analysis.}

$\mathrm{Bcl}-2$ protein distribution was presented in Tables. Data analysis was perfor-med using the SigmaStat computer program. The differences between the groups were tested by the MannWhitney Rank Sum Test (ANOVA). The re-sults were expressed as arithmetic mean (X) \pm standard deviation (SD). P $<0.05$ was taken to indicate statistical significance. Correlations between the measured $\mathrm{Bcl}-2$ protein concentration and demographic, clinical and drug treatment characteristics of patients with schizophrenia were assessed using Pearson's coefficients.

\section{Results}

Clinical and demographic characteristics of schizophrenia patients along with healthy controls are presented in Table 1

Table1. Demographic and clinical characteristics of patients with schizophrenia

\begin{tabular}{|c|c|c|c|}
\hline & & Schizophrenia & Control \\
\hline $\begin{array}{c}\text { Male /female } \\
(\mathrm{N})\end{array}$ & & $19 / 11$ & $19 / 11$ \\
\hline Age (years) & & $31.1 \pm 8.1$ & $29.1 \pm 6.9$ \\
\hline Heredity $(+/-)$ & & $12 / 18$ & \\
\hline \multirow{4}{*}{$\begin{array}{c}\text { Patient age at } \\
\text { the disease } \\
\text { onset }\end{array}$} & $<20$ & 10 & \\
\hline & $20-24$ & 4 & \\
\hline & $25-29$ & 9 & \\
\hline & $30-34$ & 7 & \\
\hline \multirow{4}{*}{$\begin{array}{c}\text { Duration of } \\
\text { psychiatric } \\
\text { disease } \\
\text { (years) }\end{array}$} & $<1$ & 5 & \\
\hline & $1-3$ & 5 & \\
\hline & $3-5$ & 8 & \\
\hline & $>5$ & 12 & \\
\hline
\end{tabular}


Both groups consisted of the same number of males and females. The age of patients at the onset of the disease was between 18 and 34 years, and the duration of psychiatric disease was between 6 months and 15 years. In 15 patients positive symptoms showed relative predomination, in 9 patients negative ones, and in 6 patients both types of symptoms were almost equally present. The heredity was present in 12 out of 30 schizophrenics.

No significant difference was found between the patient serum $\mathrm{Bcl}-2$ protein concentrations and control ones. Although the control females had the highest concentration of this protein, a statistically significant difference was not observed between males and females, either in the control or in the patient group (Table 2).

Table 2. Serum levels of $\mathrm{Bcl}-2$ protein in patients with schizophrenia

\begin{tabular}{|c||c|c||}
\hline Group & $\mathrm{n}$ & Bcl-2 $(\mathrm{ng} / \mathrm{mL})$ \\
\hline \hline Control & 30 & $0.332 \pm 0.22$ \\
\hline Schizophrenia & 30 & $0.276 \pm 0.07$ \\
\hline C-females & 11 & $0.423 \pm 0.357$ \\
C-males & 19 & $0.288 \pm 0.065$ \\
Sch-females & 11 & $0.257 \pm 0.055$ \\
Sch-males & 19 & $0.286 \pm 0.075$ \\
\hline
\end{tabular}

The results were presented as $X \pm S D$

In all three subgroups of patients classified according to the PANSS scores, similar average concentrations of serum Bcl-2 were observed (between $0.275 \pm 0.068 \mathrm{ng} / \mathrm{mL}$ and $0.283 \pm 0.082$ $\mathrm{ng} / \mathrm{mL}$ (Table 3).

Table 3. Serum Bcl-2 protein levels in schizophrenic patients with different PANSS scores

\begin{tabular}{|c||c|c||}
\hline Group of schizophrenics & $\mathrm{n}$ & $\mathrm{Bcl}-2(\mathrm{ng} / \mathrm{mL})$ \\
\hline \hline $\begin{array}{c}\text { PANSS positive score } \\
\text { predominance }\end{array}$ & 15 & $0.283 \pm 0.082$ \\
\hline $\begin{array}{c}\text { PANSS negative score } \\
\text { predominance }\end{array}$ & 9 & $0.275 \pm 0.074$ \\
\hline $\begin{array}{c}\text { PANSS positive and negative } \\
\text { equally expressed }\end{array}$ & 6 & $0.275 \pm 0.068$ \\
\hline
\end{tabular}

The results were presented as $\mathrm{X} \pm \mathrm{SD}$

However, the patients treated with second generation antipsychotics had significantly lower levels of serum Bcl-2 protein $(0.233 \pm 0.052 \mathrm{ng} /$ $\mathrm{mL}, \mathrm{p}<0.05)$ than those treated with first generation antipsychotics $(0.301 \pm 0.075 \mathrm{ng} / \mathrm{mL})$ (Table 4).

Table 4. Serum Bcl-2 protein levels in schizophrenic patients treated with the first or second generation antipsychotics.

\begin{tabular}{|c||c|c||}
\hline Group of schizophrenics & $\mathrm{n}$ & $\mathrm{Bcl}-2(\mathrm{ng} / \mathrm{mL})$ \\
\hline \hline $\begin{array}{c}\text { First generation } \\
\text { antipsychotics } \\
\text { (haloperidol) }\end{array}$ & 16 & $0.301 \pm 0.075$ \\
\hline $\begin{array}{c}\text { Second generation } \\
\text { antipsychotics } \\
\text { (clozapine or olanzapine) }\end{array}$ & 14 & $0.233 \pm 0.052 *$ \\
\hline
\end{tabular}

The results were presented as $X \pm S D$

$* p<0.05$ vs. first generation antipsychotics

In the patients with positive heredity, serum $\mathrm{Bcl}-2$ protein concentration was $0.293 \pm 0.095$ $\mathrm{ng} / \mathrm{mL}$ and was not significantly different compared to the values in negative heredity group $(0.270 \pm 0.059 \mathrm{ng} / \mathrm{mL})$. No differences were found in serum Bcl-2 concentrations related to the onset of the disease and duration of psychotic disease. There was not any significant correlation between serum $\mathrm{Bcl}-2$ concentration and heredity, first onset of the disease, number of psychotic episodes and duration of psychosis.

\section{Discussion}

According to our knowledge, this is the first study to report the concentration of $\mathrm{Bcl}-2$ protein in the sera of patients with schizophrenia. Although schizophrenia patients showed lower mean serum $\mathrm{Bcl}-2$ protein concentration, the dif-ference was not significant compared to the controls. No significant difference was found either between males and females or between the patients with different PANSS scores. However, the study limits included the following: a small number of patients, impossibility to recruit drug naive patients, inability to repeat the measure-ments of the studied markers, determination of apoptotic markers in different phases (remission and exacerbation) of the disease. In previously reported studies, apoptotic markers were investigated mostly in post-mortem brain tissue from schizophrenics. Similar to our results, Jarskog et al. (20) found $\mathrm{Bcl}-2$ protein reduction by $25 \%$ in the temporal cortex of subjects with schizophrenia. Mean $\mathrm{Bcl}-2$ levels in the treated group were $96 \%$ higher than in untreated (neuroleptic-naïve) group. Since $\mathrm{BCl}-2$ is a potent inhibitor of apoptosis, its reduction suggests that the temporal cortex in schizophrenia is more vulnerable to proapoptotic stimuli, whether those stimuli are the products of normal physiology and aging (21) or from a pathological process. The $\mathrm{Bax} / \mathrm{Bcl}-2$ ratio was also found to be $50 \%$ higher in the temporal cortex of schizophrenia patients than in nonpsychiatric comparison subjects (22). A high Bax/ $\mathrm{BCl}-2$ ratio has been also demonstrated in the cortex of brains from patients with Down's syndrome (23) and in human neuronal cultures treated with amyloid $\beta$ protein, a model for Alzheimer's disease (24). Bcl-2 protein is elevated in neurodegenerative diseases such as Alzheimer's and Parkinson's disease and the findings of Jarskog et al. (22) showed that the degenerative mechanism of schizophrenia differed substantially from classic neurodegeneration. Since Bcl-2 protein has neurotrophic properties (18), its limited reduction could promote neuronal atrophy and reduced axodendritic branching, without any effects on the cell death. On the other hand, overexpression of $\mathrm{Bcl}-2$ protein can prevent pro-apoptotic effects of ischemia, lack of growth factors and glutamate excitotoxicity (4). 
In an attempt to clarify the increased expression level of Bax encoding gene (20), as well as high $\mathrm{Bax} / \mathrm{Bcl}-2$ proteins ratio in the temporal cortex of patients with schizophrenia, Pirumyan and Boyajyan (25) evaluated the association of single nucleotide polymorphisms (SNPs) rs1057369 $(A>G)$ and $r s 956572(G>A), \operatorname{rs} 1801018(A>G)$ of Bax and $\mathrm{Bcl}-2$ encoding genes (BAX and $B C L 2$ ) with schizophrenia. BAX rs1057369 SNP was found to be negatively associated with this disorder, while the presence of BAX $\operatorname{rs} 1057369 * G$ minor allele, especially in homozygous form, was associated with a decreased risk of developing schizophrenia. No association between schizophrenia and BCL2 rs956572 and rs1801018 polymorphisms was found. The authors suggested that the rs $1057369^{*} \mathrm{G}$ minor allele of BAX may have a protective effect against schizophrenia, and that this effect is most pronounced in subjects with the GG homozygous genotype. In the study including the patients with bipolar disorder and those with schizophrenia, Benes et al. (26) showed a marked up-regulation of 19 out of 44 apoptosis genes in bipolar disorder, while the schizophrenia group showed a down-regulation of genes associated with apoptotic injury and death. The second reason for the dysregulation of pro- and antiapoptotic proteins in schizophrenia may be neuroleptics used in the treatment of schizophrenia. There are indices that anti-psychotic drugs may affect the expression of $\mathrm{Bcl}-2$ protein and that these drugs can influence the regulation of apoptosis in the CNS by activating both pro- and antiapoptotic pathways $(27)$. Both typical $(28,29)$ and atypical (29 ) antipsychotic drugs have been found to promote cell survival, although atypical agents may be more effective in this regard (30). Contrary to this finding, our results showed a significantly lower serum Bcl-2 concentration in patients treated with second generation antipsychotics than that obtained in patients treated with first generation antipsychotics. This finding is consistent with our previously published results related to an increased lymphocyte caspase-3 activity in patients with schizophrenia (31). These results indicate that the process of apoptosis is dysregulated in schizophrenia and may be the cause of nonletal apoptosis, as suggested by a number of authors. Moreover, the typical agent perphenazine has been found to increase DNA fragmentation
(32), while clozapine may act as a hapten and increase the inflammatory potential (33). Clozapine has also been shown to activate Akt, which is a prosurvival factor that in its active form inhibits glycogen synthase kinase- $3 \beta$ responsible for intracellular signaling towards cell death (34). Although there is evidence that atypical antipsychotics upregulate $\mathrm{Bcl}-2$ mRNA and protein (35) in rat frontal cortex, Jarskog et al. (36) do not confirm that finding. They studied the effects of haloperidol, clozapine, quetiapine, or saline on multiple apoptotic markers, including $\mathrm{Bcl}-2$, pro-apoptotic Bax, anti-apoptotic XIAP, and the downstream protease caspase-3 in rat frontal cortex using Western blot. The obtained results showed that immunereactivity of $\mathrm{Bax}$ and $\mathrm{Bcl}-2$ bands were unchanged with the treatment. However, the mean density of the activated caspase- 3 band was 55\% higher with haloperidol ( $p<0.001), 40 \%$ higher with clozapine $(p<0.05)$, and $48 \%$ higher with quetiapine ( $p<0.01)$ compared to saline controls. The specific activity of caspase-3 was also increased across all treatments ( $p<0.0001)$, while DNA fragmentation rates remained unchanged. These data suggest that subchronic antipsychotic treatment is associa-ted with non-lethal caspase-3 activity.

\section{Conclusion}

There was not any significant difference in serum $\mathrm{BCl}-2$ concentrations between schizophrenics and control subjects. Serum Bcl-2 protein concentration in patients treated with second generation antipsychotics was significantly lower compared to the values obtained in patients receiving first generation antipsychotics. No significant correlation was found between serum Bcl-2 concentration and heredity, onset of the disease, number of psychotic episodes and duration of psychosis.

\section{Conflict of interest statement}

The results presented in this paper have not been published previously in whole or part, except in abstract form. The author reports no conflicts of interest. The author alone is responsible for the content and writing of the paper. 


\section{References}

1. Lublin H. Cognitive dysfunction in schizophrenia. Acta Psychiatr Scand Suppl 2001; 104: 5-9. [CrossRef]

2. Matza LS, Buchanan R, Purdon S, Brewster-Jordan J, Zhao Y, Revicki DA. Measuring changes in functional status among patients with schizophrenia: the link with cognitive impairment. Schizophr Bull 2006; 32: 666-78. [CrossRef] [PubMed]

3. Zahir FR, Brown CJ. Epigenetic impacts on neurodevelopment: pathophysiological mechanisms and genetic modes of action. Pediatr Res 2011; 69: 92R-100R. [CrossRef][PubMed]

4. Jarskog LF, Glantz LA, Gilmore JH, Lieberman JA. Apoptotic mechanisms inthe pathophysiology of schizophrenia. Prog Neuropsychopharmacol Biol Psychiatry 2005; 29: 846-58.[PubMed]

5. Olney JW. Excitotoxicity, apoptosis and neuropsy chiatric disorders. Curr Opin Pharmacol 2003; 3: 101-9. [CrossRef][PubMed]

6. Mattson MP, Keller JN, Begley JG. Evidence for synaptic apoptosis. Exp Neurol 1998; 153: 35-48. [CrossRef][PubMed]

7. Glantz LA, Gilmore JH, Overstreet DH, Salimi K, Lieberman JA, Jarskog LF. Pro-apoptotic Par-4 and dopamine D2 receptor in temporal cortex in schizophrenia, bipolar disorder and major depression. Schizophr Res 2010; 118: 292-9. [CrossRef] [PubMed]

8. Djordjevic VV, Ristic T, Lazarevic D, Cosic V, Vlahovic $P$, Djordjevic VB. Schizophrenia iss associated with increased levels of serum Fas and FasL. Clin Chem Lab Med 2012; 50: 1049-54. [CrossRef][PubMed]

9. Glantz LA, Gilmore JH, Lieberman JA, Jarskog LF. Apoptotic mechanisms and synaptic pathology of schizophrenia. Schizophr Res 2006; 81: 47-63. [CrossRef][PubMed]

10. Perez-Neri I, Ramirez-Bermudez J, Montes S, Rios C. Possible mechanisms of neurodegeneration in schizophrenia. Neurochem Res 2006; 31: 1279-94. [CrossRef][PubMed]

11. Muller $N$, Schwarz MJ. Immune system and schizophrenia. Curr Immunol Rev 2010; 6: 213-20. [CrossRef][PubMed]

12. Adams JM, Cory S. The Bcl-2 protein family: arbiters of cell survival. Science 1998; 281: 13226. [CrossRef][PubMed]

13. Reed JC. Bcl-2 family proteins. Oncogene 1998; 17: 3225-36. [CrossRef] [PubMed]

14. Roset R, Ortet L, Gil-Gomez G. Role of Bcl-2 family members on apoptosis: what we have learned from knockout mice. Front Biosci 2007; 12: 4722-30. [CrossRef][PubMed]

15. Youle RJ, Strasser A. The Bcl-2 protein family: opposing activities that mediate cell death. Nat Rev Mol Cell Biol 2008; 9: 47-59. [CrossRef][PubMed]

16. Yang J, Liu X, Bhalla K, Kim CN, Ibrado AM, Cai J, et al. Prevention of apoptosis by $\mathrm{BCl}-2$ : release of cytochrome c from mitochondrial blocked. Science 1997; 275: 1129-32. [CrossRef][PubMed]

17. Chen G, Manji HK. The extracellular signalregulated kinase pathway: An emerging promising target for mood stabilizers. Curr Opin Psychiatry 2006; 19: 313-23. [CrossRef][PubMed]

18. Chen DF, Schneider GE, Martinou JC, Tonegawa S. $\mathrm{BCl}-2$ promotes regeneration of severed axons in mammalian CNS. Nature 1997; 385: 435-9. [CrossRef][PubMed]
19. Jonas $\mathrm{E}$. BCl-xl regulates synaptic plasticity. Mol Interv 2006; 6: 208-22. [CrossRef][PubMed]

20. Jarskog LF, Gilmore JH, Sekinger ES, Lieberman JA. Cortical Bcl-2 protein expression and apoptotic regulation in schizophrenia. Biol Psychiatry 2000; 48: 641-50. [CrossRef][PubMed]

21. Mrak RE, Griffin WST, Graham DI. Aging associated changes in human brain. J Neuropathol Exp Neurol 1997; 56: 1269-75. [CrossRef][PubMed]

22. Jarskog LF, Selinger ES, Lieberman JA, Gilmore JH. Apoptotic proteins in the temporal cortex in schizophrenia: high Bax/Bcl-2 ratio without caspase-3 activation. Am J Psychiatry 2004; 161:109-15. [CrossRef][PubMed]

23. Sawa A, Oyama F, Cairns NJ, Amano N, Matsushita M. Aberrant expression of bcl-2 gene family in Down's syndrome brains. Mol Brain Res 1997; 48: 53-9. [CrossRef] [PubMed]

24. Paradis E, Douillard H, KoutroumanisM, Goodyer C, LeBlanc A. Amyloid $\beta$ peptide of Alzheimer's disease downregulates $\mathrm{BCl}-2$ and upregulates $\mathrm{Bax}$ expression in human neurons. J Neurosci 1996; 16: 7533-9.[PubMed]

25. Pirumyan K, Boyajyan A. Study of association between schizophrenia and functional polymor phisms of genes encoding $\mathrm{Bcl}-2$ family proteins. Int J Biol Sci Appl 2014; 1: 28-34.

26. Benes FM, Matzilevich D, Burke RE, Walsh J. The expression of proapoptosis genes is increased in bipolar disorder, but not in schizophrenia. Mol Psychiatry 2006; 11: 241-51. [CrossRef][PubMed]

27. Jarskog LF. Apoptosis in schizophrenia: patho physiologic and therapeutic considerations. Curr Opin Psychiatry 2006; 19: 307-12. [CrossRef] [PubMed]

28. Achour A, Lu W, Arlie M, Cao L, Andrieu JMT. Cell survival/proliferation reconstitution by trifluoperazine in human immunodeficiency vrus-1 infection. Vitology 2003; 315: 245-58. [CrossRef] [PubMed]

29. Wei Z, Bai O, Richardson JS, Mousseau DD, Li XM. Olanzapine protects $\mathrm{PC} 12$ cells from oxidative stress induced by hydrogen peroxide. J Neurosci Res 2003; 73: 364-68. [CrossRef][PubMed]

30. Qing $H$, Xu H, Wei Z, Gibson K, Li XM. The ability of atypical antipsychotic drugs vs. haloperidol to protect PC 12 cells: against, MPP+-induced apoptosis. Eur J Neurosci 2003; 17: 1563-70. [CrossRef][PubMed]

31. Lazarević D, Đorđević VV, Ćosić V, Vlahović $P$, Tošić-Golubović S, RistićT, Đorđević BV. Increased lymphocyte caspase- 3 activity in patients with schizophrenia. J Med Biochem 2011; 30: 55-61. [CrossRef]

32. Gil-ad I, Shtaif B, Shiloh R, Weizman A. Evaluation of the neurotoxic activity of typical and atypical neuroleptics: relevance to iatrogenic extra pyramidal symptoms. Cell Mol Neurobiol 2001; 21: 705-16. [CrossRef] [PubMed]

33. Haack MJ, Bak ML, Beurskens R, Maes M, Stolk LM, Delespaul PA. I. Toxic rise of clozapine plasma concentrations in relation to inflammation. Eur Neuropsychopharmacol 2003; 13: 381-5. [CrossRef] [PubMed]

34. Kang UG, Seo MS, Roh MS, Kim Y, Yoon SC, Kim YS. The effects of clozapine on the GSK-3-mediated signaling pathway. FEBS Lett 2004; 560: 115-9. [CrossRef][PubMed] 
35. Bai O, Zhang H, Li XM. Antipsychotic drugs clozapine and olanzapine upregulated $\mathrm{Bcl}-2$ mRNA and protein in rat frontal cortex and hippocampus. Brain Res 2004; 1010: 81-6. [CrossRef][PubMed]
36. Jarskog LF, Gilmore JH, Glantz LA, Gable KL, German TT, Tong RI, Lieberman JA.Caspase-3 activation in rat frontal cortex following treatment with typical and atypical antipsychotics. Neuro psychopharmacology 2007; 32: 95-102. [CrossRef] [PubMed]

\title{
NIŽI NIVO BCL-2 PROTEINA U SERUMU OBOLELIH OD SHIZOFRENIJE TRETIRANIH DRUGOM U ODNOSU NA TRETIRANE PRVOM GENERACIJOM ANTIPSIHOTIKA
}

\author{
Vladimir V. Đorđević1,2 \\ ${ }^{1}$ Univerzitet u Nišu, Medicinski fakultet, Niš, Srbija \\ ${ }^{2}$ Klinika za zaštitu mentalnog zdravlja, Klinički centar Niš, Niš, Srbija \\ Kontakt: Vladimir V. Đorđević \\ Bul. Dr Zorana Đinđića 81, 18000, Niš, Srbija \\ E-mail: vladimir_dj@open.telekom.rs
}

\begin{abstract}
Shizofrenija je jedna od najtežih psihijatrijskih bolesti nepoznate etiologije. Među mnogim faktorima koji su uključeni u patofiziologiju shizofrenije razmatrana je i uloga apoptoze. Bcl-2 protein je potentni inhibitor apoptoze koji takođe pokazuje neurotropnu aktivnost u centralnom nervnom sistemu. Kako je ekspresija Bcl-2 proteina povećana u nekoliko neurodegenerativnih bolesti, a shizofrenija pokazuje neke karakteristike limitiranog neurodegenerativnog poremećaja postavljena je hipoteza da je ekspresija Bcl2 proteina poremećena u shizofreniji. Da bismo testirali ovu hipotezu, Bcl-2 protein je određivan u serumu 30 bolesnika sa shizofrenijom i 30 zdravih osoba ELISA metodom. Mada je srednja vrednost koncentracije $\mathrm{Bcl}-2$ proteina u serumu bolesnika sa shizofrenijom bila niža u odnosu na kontrolnu grupu, nije bilo značajne razlike između vrednosti bolesnika $(0,276 \pm 0,07 \mathrm{ng} / \mathrm{mL})$ i zdravih ispitanika $(0,332 \pm 0,22 \mathrm{ng} / \mathrm{mL})$. Nije nađena značajna razlika između muškaraca i žena. Slične vrednosti serumske koncentracije $\mathrm{Bcl}-2$ proteina dobijene su u podgrupi bolesnika sa podjednako izraženom pozitivnom i negativnom simptomatologijom $(0,275 \pm 0,068 \mathrm{ng} / \mathrm{mL})$, u podgrupi sa relativnom predominacijom pozitivnih simptoma $(0,283 \pm 0,082 \mathrm{ng} / \mathrm{mL})$ i u podgrupi sa relativnom predominacijom negativnih simptoma $(0,275 \pm 0,074 \mathrm{ng} / \mathrm{mL})$. Koncentracija $\mathrm{Bcl}-2$ proteina u serumu bolesnika tretiranih prvom generacijom antipsihotika bila je $0,301 \pm 0,075 \mathrm{ng} / \mathrm{mL}$, i značajno viša u poređenju sa vrednostima bolesnika koji su lečeni drugom generacijom antipsihotika $(0,233 \pm 0,052 \mathrm{ng} / \mathrm{mL}, \mathrm{p}<0,05)$. Nije nađena značajna korelacija koncentracije $\mathrm{Bcl}-2$ proteina i herediteta, vremena početka bolesti, broja psihotičnih epizoda i dužine trajanja bolesti. Prema našim saznanjima, ovo je prvi prikaz koncentracije Bcl-2 proteina u serumu bolesnika sa shizofrenijom koji je pokazao značajnu razliku između bolesnika tretiranih prvom i onih tretiranih drugom generacijom antipsihotika.
\end{abstract}

Acta Medica Medianae 2017;56(4):126-131.

Ključne reči: shizofrenija, serum, Bcl-2 protein, antipsihotici 